\title{
PENGARUH KOMITMEN ORGANISASIONAL TERHADAP KINERJA ISLAMI DI PT. TERAFULK MEGANTARA DESIGN SURABAYA
}

\author{
Soraya Rizky Widyanti \\ Mahasiswa Program StudiS 1Ekonomi Islam- Fakultas Ekonomi dan Bisnis UniversitasAirlangga \\ Email:world_ay@rocketmail.com
}

Ari Prasetyo

Departemen Ekonomi Syariah - Fakultas Ekonomi dan Bisnis - Universitas Airlangga Email: ari.prasetyo@feb.unair.ac.id

\begin{abstract}
Low and high level of employee's Islamic performance could be affected by a employee's commitment toward company or organization, that's called organizational commitment. This study aims to know and find the effect of organizational commitment toward employee's islamic performance. The study was carried out at Terafulk Megantara Design Surabaya Ltd.

The used approach was quantitative approach and data collection was implemented by using a questionnaire with a number of samples 50 employees. Method of data collection use nonprobability sampling technique by approach of saturated sampling. The analysis technique that's used in this study was simple linear regression.

The result of study proved that organizational commitment had positive and significant effect toward employee's Islamic performance, where employee's Islamic performance had increased if organizational commitment increased and vice versa.
\end{abstract}

\section{Key words: Commitment, Organizational Commitment, Performance, Islamic Performance}

\section{Pendahuluan \\ Latar Belakang}

Perubahan - perubahan yang selalu terjadi akibat adanya globalisasi cenderung mempengaruhi kondisi ekonomi negara Indonesia. Dengan adanya globalisasi setiap perusahaan selalu didorong untuk mencapai efektivitas dan efesiensi agar memiliki daya saing yang kuat, untuk dapat bertahan pada ketatnya persaingan perusahaan di Indonesia, khususnya di bidang jasa. dimana setiap perusahaan dituntut untuk menciptakan strategi khusus dalam memberikan pelayanan yang lebih kepada para konsumen agar mereka merasa nyaman dan percaya akan layanan jasa yang diberikan (Azizah, 2013 : 5). Oleh karena itu perlu adanya unsur sumber daya manusia yang berkualitas baik dalam berpikir, bertindak, serta terampil dalam menjalankan pekerjaannya, sehingga dapat mencapai hasi kerja (kinerja) yang poduktif.

Kinerja merupakan bentuk kontribusi yang diberikan seorang karyawan bagi pencapaian tujuan - tujuan organisasi atau perusahaan. Sedangkan kinerja seseorang merupakan gabungan kemampuan, usaha, dan kesempatan, yang dapat diukur dari akibat yang dihasilkannya. Menurut Wibowo (2011:4), Implementasi dari rencana yang telah disusun disebut sebagai kinerja. Dimana implementasi kinerja dilakukan oleh sumber daya manusia yang memiliki kemampuan, kompetensi, motivasi, dan kepentingan. Karyawan dikatakan Jurnal ini merupakan bagian dari skripsi yang ditulis oleh Soraya Rizky .W. NIM 041014104 yang diuji pada 29 November 2016 
sebagai karyawan produktif apabila memiliki tingkat kinerja yang tinggi sedangkan yang levelnya tidak mencapai standar atau kinerja rendah disebut karyawan tidak produktif.

Salah satu faktor yang dapat mempengaruhi tingkat kinerja (level of perfomance) seorang karyawan adalah komitmen. Komitmen memiliki peranan penting terutama pada kinerja seseorang dalam bekerja. Hal ini dikarenakan komitmen merupakan acuan untuk mencapai visi dan misi perusahaan. Dan adanya komitmen membuat para karyawan lebih bertanggung jawab terhadap kewajibannya. Oleh karena itu, komitmen organisasional merupakan modal dasar bagi semua karyawan, karena semakin kuat komitmen para karyawan maka semakin tinggi tingkat kinerja mereka (Khaerul Umam, 2012 : 258).

Dalam Islam, istilah kerja tidak hanya untuk mencari rezeki guna memenuhi kebutuhan hidup diri sendiri dan keluarga, tetapi juga mencakup bentuk amalan yang memiliki unsur kebaikan serta keberkahan bagi diri sendiri, keluarga, dan lingkungan (Azizah, 2012 : 30).

Sejak diberlakukannya UU No. 51/2002 tentang perkapalan, pada pasal 2 mengenai pengadaan, pembangunan, dan pengerjaan kapal, PT. Terafulk Megantara Design resmi didirikan oleh DR. Khairuddin Djenod Daeng Manyaembang, M.Eng, pada tgl 10 November 2005 di Surabaya. PT. Terafulk Megantara Design merupakan sebuah perusahaan yang bergerak di bidang layanan jasa dengan memfokuskan diri pada pembuatan desain kapal.

Untuk menghadapi persaingan dalam industri perkapalan, Terafulk membentuk tiga anak perusahaan, yaitu terdiri dari PT. Terafulk Global Biz yang bergerak di bidang pengadaan material kapal dan general trading, PT. Terafulk Multimedia membatu para engineer dalam mendesain tampilan interior kapal dan mengembangkan purwarupa software desain kapal, dan Tunas Terafulk Lines yaitu perusahaan pelayaran dan Terafulk Hydrocraft Indonesia yaitu persahaan galangan. [ Fanda, 2013 : 55).

Berdasarkan hasil observasi dan informasi yang di dapat, meskipun PT. Terafulk Megantara Design merupakan perusahaan swasta pada umumnya, namun yang membedakan perusahaan ini dengan perusahaan lain adalah penerapan peraturan - peraturan perusahaan yang berlandaskan Islami, seperti untuk tetap menjaga kebersihan lantai para karyawan dan tamu harus melepaskan sepatu mereka saat masuk ke dalam kantor dan menggantinya dengan sandal khusus yang telah disediakan. Karena seluruh karyawan dalam perusahaan ini beragama Islam, maka perusahaan mewajibkan setiap karyawan untuk menjalankan shalat fardhu secara berjamaah dan mengadakan pengajian serta memberikan kajian - kajian Islam yang dilakukan setiap bulannya dengan tujuan agar para karyawan lebih mengetahui 
dan memahami secara mendalam mengenai agama Islam, serta tetap menjaga tali silaturahmi, baik diantara para karyawan maupun karyawan dengan atasan. Untuk meningkatkan semangat Islami dan kinerja para karyawannya, beberapa tahun sekali PT. Terafulk Megantara Design memberikan kesempatan kepada para karyawan berupa pemberangkatan dua sampai tiga orang karyawan untuk pergi umroh secara bergantian. Hal ini dilakukan tidak hanya bertujuan untuk meningkatkan rasa cinta dan ketaqwaan para karyawan kepada Allah SWT, selain itu bertujuan meningkatkan komitmen para karyawan terhadap perusahaan untuk terus memberikan kontribusi dan hasil kerja yang lebih produktif demi tercapainya tujuan - tujuan perusahaan. Penelitian ini dilakukan dengan tujuan Untuk mengetahui pengaruh komitmen organisasional terhadap kinerja Islami karyawan pada PT. Terafulk Megantara Design Surabaya.

\section{Landasan Teori dan Hipotesis}

\section{A. Komitmen Organisasional}

Keberhasilan dalam mengelolah suatu organisasi atau perusahaan sangat ditentukan pada pengelolahan sumber daya manusia (karyawan). Tinggi rendahnya komitmen karyawan terhadap organisasi tempat mereka bekerja sangat berpengaruh terhadap kinerja mereka guna tercapainya tujuan organisasi. Komitmen karyawan memiliki pengaruh besar dalam dunia kerja. Bahkan beberapa perusahaan memasukkan unsur komitmen sebagai salah satu syarat dalam penerimaan karyawan baru. Namun para karyawan maupun pemilik perusahaan perlu memahami arti komitmen yang sebenarnya. Sebab pemahaman tersebut sangat penting bagi organisasi agar tercipta kondisi kerja yang kondusif, sehingga organisasi atau perusahaan dapat berjalan secara efisien dan efektif.

\section{Pentingnya Komitmen Organisasional dalam Islam}

Memiliki sebuah komitmen berarti memiliki sebuah tujuan yang ingin dicapai, oleh karena itu Islam mengajarkan setiap umat muslim untuk berkomitmen selalu beribadah kepada Allah SWT dan berpedoman pada Al Qur'an dan Hadist guna bertujuan untuk mendapatkan kemaslahatan hidup baik di dunia maupun di akhirat. Menurut Tasmara ((2006:62) dalam Astria, 2014:43), komitmen adalah keyakinan yang mengikat (aqad) sedemikian kukuhnya sehingga membelenggu seluruh hati nuraninya dan kemudian menggerakkan perilaku menuju arah tertentu yang diyakininya (i'tiqad).

Oleh karena itu memiliki komitmen kerja yang Islami dalam diri akan membuat kita sebagai karyawan muslim untuk selalu berpikir bahwa setiap pekerjaan yang kita lakukan adalah sebagai bentuk ibadah kepada Allah SWT, bersedia dan rela untuk melakukan pekerjaan sebagai hamba Allah SWT dan memiliki keteguhan hati serta rasa tanggung 
jawab tinggi dan konsisten dalam pekerjaannya. Pentingnya komitmen dalam Islam didasari pada Alqur'an surah al - Ahqaaf ayat 13, yang berbunyi :

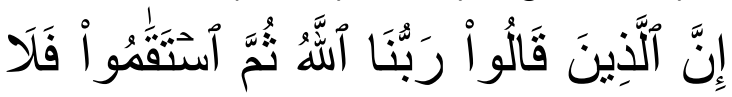

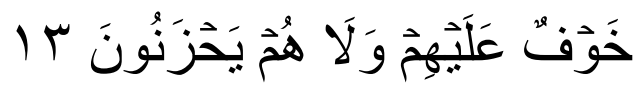

Innal-ladziina qaaluuv rabbunaallahu tsummaastaqaamu falaa khaufun 'alaihim walaahum yahzanuun(a)

"Sesungguhnya orang-orang yang mengatakan: "Tuhan kami ialah Allah", kemudian mereka tetap istiqamah maka tidak ada kekhawatiran terhadap mereka dan mereka tiada (pula) berduka cita".(Depag Rl, 2006: 726)

\section{B. Kinerja Islami}

$\begin{array}{crr}\text { Suatu } & \text { perusahaan tentu } \\ \text { membutuhkan } & \text { karyawan sebagai }\end{array}$

tenaga kerja untuk meningkatkan produk yang berkualitas. Mengingat karyawan merupakan asset penting bagi perusahaan, banyak hal yang perlu diperhatikan terkait peningkatan kinerjanya (Robbins and Judge, 2016 : 331).

Kinerja adalah catatan mengenai akibat - akibat yang dihasilkan pada sebuah fungsi pekerjaan atau aktivitas selama periode tertentu yang berhubungan dengan tujuan organisasi (Khaerul Umam, 2012 : 257). Menurut Wibowo (2011:4), implementasi atau pelaksanaan dari rencana - rencana yang telah disusun disebut sebagai kinerja, dimana pelaksanaan kinerja dilakukan oleh sumber daya manusia yang memiliki kemampuan, kompetensi, motivasi, dan kepentingan.
Sedangkan Dalam Islam, istilah kerja tidak hanya untuk mencari rezeki guna memenuhi kebutuhan hidup diri sendiri dan keluarga, tetapi juga mencakup bentuk amalan yang memiliki unsur kebaikan serta keberkahan bagi diri sendiri, keluarga, dan lingkungan (Azizah, $2012: 30)$.

Kinerja Islami merupakan dimensi kinerja modern dalam tuntunan Islam namun lebih komprehensif, dimana pencapaian kinerja tidak hanya untuk kepentingan dunia, tetapi juga kepentingan akhirat. Bekerja tidak hanya dilakukan dengan baik tetapi juga dengan benar, karena Allah telah menjanjikan balasan yang baik bagi siapa saja yang melakukan amal shaleh. Sebagaimana dalam dalam AlQur'an surat An-Nahl ayat 97 yang berbunyi :

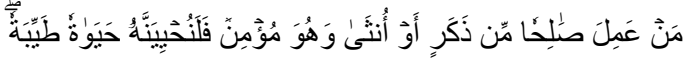

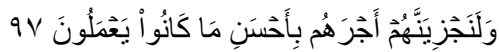

Man 'amila shaalihan min dzakarin au untsa wahuwa mu'minun falanuhyiyannahu hayaatan thai-yibatan walanajziyannahum ajrahum biahsani maa kaanuu ya'maluun(a)

"Barangsiapa yang mengerjakan amal saleh, baik laki-laki maupun perempuan dalam keadaan beriman, maka sesungguhnya akan Kami berikan kepadanya kehidupan yang baik dan sesungguhnya akan Kami beri balasan kepada mereka dengan pahala yang lebih baik dari apa yang telah mereka kerjakan"(Depag RI, 2006:378).

Islam juga memperhatikan bagaimana cara kerja atau kinerja umat muslim dalam melakukan pekerjaan dengan menganjurkan pada setiap ummat Islam untuk memiliki kinerja yang bersifat Islami yaitu berkualitas, baik, tepat, dan teratur serta sesuai dengan syariat 
Islam. Dalam hadistnya Rasulullah SAW bersabda bahwa:

"Sesungguhnya Allah menyukai orang orang yang jika mengerjakan tugas dilaksanakan dengan Itqon (sesuai tujuan, target, dan sebaik - baiknya)". (HR. Tabrani)

Dari hadist di atas dijelaskan bahwa setiap individu harus selalu memberikan manfaat menjalankan setiap aktivitas pekerjaannya secara proporsional, progresif, serta sesuai dengan prosedur dan tepat waktu, sehingga dapat diselesaikan sesuai dengan tujuan, target, dan hasil yang diinginkan. Menurut Wibisono (2002), suatu pencapaian kerja yang diperoleh oleh seseorang karyawan dalam bekerja atau berusaha dengan mengikuti kaidah - kaidah agama dan prinsip ekonomi Islam dinamakan kinerja religious. Sedangkan Menurut Mul Irawan (2014) Islam memiliki beberapa unsur dalam melakukan penilaian kinerja suatu usaha atau kegiatan, antara lain :

\section{Pentingnya Kinerja Islami dalam Perusahaan}

Kinerja Islami adalah tingkat pencapaian hasil yang diperoleh melalui bekerja atau berusaha dengan mengikuti kaidah - kaidah syariah serta prinsip prinsip Islam yang berlandaskan Al Qur'an dan Hadist. Karyawan muslim yang memiliki kinerja Islami senantiasa memiliki sikap profesional, jujur, sopan, dan tekun dalam bekerja, serta memahami tata nilai bekerja sesuai syariat Islam. Sikap karyawan yang seperti inilah justru akan
1. Bekerja sebagai bentuk niat beribadah kepada Allah SWT.

2. Bekerja harus sesuai dengan kaidah, norma, atau syariat Islam.

3. Motivasi bekerja adalah untuk mencari kemaslahatan di dunia dan akhirat.

4. Tetap menjaga kelestarian lingkungan dengan menerapkan efesiensi dan manfaat bekerja.

5. Mencari keseimbangan antara harta dan Ibadah.

6. Selalu bersyukur kepada Allah SWT atas keberhasilan yang diterima dalam pekerjaan.

Dalam Islam, bekerja bukan sekedar untuk memenuhi kebutuhan hidup tetapi untuk memelihara harga diri dan martabat yang harus dijunjung tinggi. Karenanya bekerja dalam Islam menempati posisi yang amat mulia dan bahkan disebut sebagai jihad fi sabilillah (Irawan, 2014 : 27).

meningkatkan citra perusahaan tersebut di mata konsumen (Azizah, 2012 : 36).

\section{Hubungan Komitmen Organisasional Terhadap Kinerja Islami Karyawan}

Hubungan antara komitmen organisasional dengan kinerja karyawan cenderung memiliki hubungan yang positif, artinya terdapat hubungan yang searah antar kedua variabel. Dimana kinerja karyawan akan mengalami peningkatan apabila komitmen organisasional mengalami kenaikan, dan kinerja karyawan ikut mengalami penurunan apabila komitmen 
organisasional juga mengalami penurunan (Yetta Tri, 2012 : 97).

Karyawan yang memiliki tingkat komitmen yang tinggi cenderung menghasilkan kinerja yang tinggi pula karena mereka akan memberikan kesetiaan, memiliki keinginan, serta berusaha bekerja lebih keras, berkorban, dan sangat peduli pada kelangsungan hidup perusahaan sehingga mereka akan bekerja semaksimal mungkin dan memiliki keinginan kuat untuk mencapai tujuan organisasi. Dan sebaliknya,

\section{Kerangka Pemikiran}

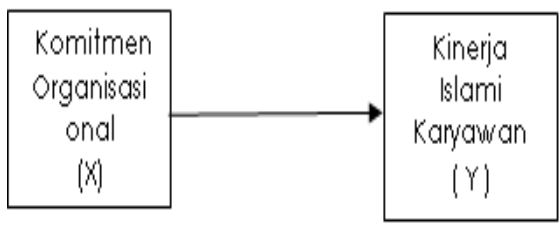

\section{Gambar 2.1}

\section{Kerangka Pemikiran}

\section{METODE PENELITIAN}

Pendekatan penelitian yang digunakan dalam penelitian ini adalah penelitian secara kuantitatif, melalui tiga tahap komponen yakni dengan mengadakan pengambilan hipotesis, pengukuran data, dan pengambilan kesimpulan.

Data yang akan digunakan dalam penelitian ini merupakan data primer yang diperoleh dari hasil survei dengan penyebaran kuisioner kepada responden yang dilakukan pada para karyawan PT. Terafulk Megantara Design Surabaya, dan data sekunder yang diperoleh dari literatur - literatur dan penelitian - penelitian sebelumnya yang memiliki keterkaitan dengan permasalahan ini. Hasil survei karyawan yang memiliki tingkat komitmen yang rendah akan bekerja dengan perasaan terpaksa dan tidak maksimal sehingga akan menghasilkan tingkat kinerja yang rendah pula.

Oleh karena itu, berdasarkan hasil dari penelitian sebelumnya di atas, peneliti mencoba mencari tahu hubungan antara komitmen organisasional terhadap kinerja karyawan dimana variabel kinerja yang digunakan adalah kinerja dalam perspektif Islam.

penelitian yang merupakan jawaban dari responden nantinya akan diolah dan dianalisis dengan menggunakan teknik analisis regresi linear berganda dengan program SPSS (Statistical Program Social Science).

\section{Variabel Bebas (X)}

Variabel bebas $(X)$ dalam penelitian ini adalah komitmen organisasional karyawan pada PT. Terafulk Megantara Design Surabaya. Komitmen organisasional merupakan suatu keadaan dimana seorang karyawan memihak suatu organisasi (perusahaan) tertentu serta tujuan - tujuan dan keinginannya untuk mempertahankan keanggotaannya dalam organisasi tersebut. Variabel komitmen organisasional pada penelitian ini memiliki enam indikator yang terdiri dari :

1. Karyawan merasa senang bekerja dalam perusahaan.

2. Karyawan merasa puas atas kebijakan yang dibuat dalam perusahaan. 
3. Karyawan tidak memiliki alternatif kerja di tempat lain.

4. Karyawan akan mendapatkan kesulitan dalam hidup jika meninggalkan perusahaan

5. Karyawan memiliki kewajiban untuk terus bekerja lebih keras demi keberhasilan perusahaan.

6. Karyawan memiliki keinginan untuk tetap bertahan di dalam perusahaan.

\section{Variabel Bergantung ( $Y$ )}

Variabel bergantung ( $Y$ ) pada penelitian ini adalah kinerja Islami karyawan pada PT. Terafulk Megantara Design Surabaya. Variabel kinerja Islami karyawan pada penelitian ini terdiri dari enam indikator, antara lain :

1. Karyawan Istiqomah waktu dalam menyelesaikan pekerjaan.

2. Karyawan Istiqomah waktu dalam bekerja.

3. Karyawan dapat menyelesaikan pekerjaannya sesuai ketentuan Islam yaitu mencapai dan atau melebihi target yang ditentukan.

4. Karyawan memberikan hasil kerja (kinerja) yang berkualitas baik sesuai syariah

maupun sesuai dengan standar perusahaan.

5. Perusahaan mampu mengeluarkan ZIS (Zakat, Infaq, dan Shadaqah) dari hasil kerja

(kinerja) yang dicapai karyawan selama periode tertentu.
6. Karyawan memiliki kreativitas dalam mengembangkan kemampuan diri.

Kedua variabel ini diukur dengan menggunakan rating-scale. Para responden akan menentukan tingkat persetujuan mereka terhadap suatu pernyataan dengan memilih salah satu dari empat skala pilihan yang tersedia, sebagai berikut :

\begin{tabular}{|l|l|}
\hline Jawaban & Skor \\
\hline a. Sangat Setuju & 4 \\
\hline b. Setuju & 3 \\
\hline c. Tidak Setuju & 2 \\
\hline $\begin{array}{l}\text { d. Sangat Tidak } \\
\text { Setuju }\end{array}$ & 1 \\
\hline
\end{tabular}

Metode Penentuan Sampel, Uji Validitas, Uji Reliabilitas, dan Uji Regresi

Dalam penelitian ini, teknik sampling yang digunakan adalah teknik nonprobability sampling dan pada penentuan sampel digunakan metode sampling jenuh, yaitu teknik penentuan sampel dengan semua anggota populasi digunakan sebagai sampel, sehingga tidak perlu menggunakan kriteria responden. Jumlah populasi pada penelitian ini sekitar 50 karyawan PT. Terafulk Megantara Design Surabaya. Oleh karena itu sampel yang digunakan adalah seluruh jumlah populasi sekitar 50 responden.

Uji validitas merupakan suatu ukuran yang menunjukkan tingkat kesahihan suatu instrumen (alat ukur).

Uji reliabilitas adalah suatu ukuran yang apabila digunakan beberapa kali untuk 
mengukur obyek yang sama akan menghasilkan data (ukuran) yang sama (Anshori dan Iswati, 2009:75).

Uji yang dilakukan untuk mengetahui apakah model regresi yang dihasilkan merupakan model regresi yang menghasilkan estimasi linier tidak bias dan memenuhi kaidah BLUE (Best Linear Unbiased Estimator) maka perlu dilakukan pengujian gejala penyimpangan asumsi model klasik

\section{Teknik Analisis Data}

Teknik analisi data yang digunakan untuk memecahkan permasalahan dalam penelitian ini menggunakan analisis regresi sederhana yang berfungsi untuk mengetahui pengaruh atau hubungan antara variabel bebas (X) yaitu komitmen organisasional dengan variabel bergantung $(\mathrm{Y})$ yaitu kinerja islami karyawan pada PT. Terafulk Megantara Desaign Surabaya. Berdasarkan dengan variabel - variabel yang digunakan, maka hubungan antar variabel dapat dinyatakan dalam fungsi sebagai berikut : Bentuk persamaan regresi linier sederhana dapat dirumuskan sebagai berikut :

$Y=a+\beta_{1} X+e$

\section{Koefisien Determinasi}

Koefisien ini berguna untuk mengetahui besarnya pengaruh variabel bebas (X) terhadap variabel bergantung ( $Y$ ) yang diperoleh dengan mengkuadratkan koefisien kolerasinya $\left(R^{2}\right)$. Jonathan Sarwono (2006:50) mengemukakan bahwa koefisien determinasi (KD) dilakukan dengan menggunakan rumus sebagai berikut : $K D=r^{2} \times 100 \%$

\section{Uji Hipotesis}

Uji hipotesis yang digunakan dalam penelitian ini adalah uji $F$ dan uji $t$, sebagai berikut:

Uji $F$ digunakan untuk mengetahui pengaruh variabel bebas terhadap variabel terikat secara simultan. Adapun pengambilan keputusan dalam uji $F$ ini adalah sebagai berikut:

Jika nilai signifikansi lebih kecil daripada besarnya nilai tingkat signifikan (a) yaitu 0,05, maka $\mathrm{H}_{0}$ ditolak dan $\mathrm{H}_{1}$ diterima, dan sebaliknya

Sedangkan Uji † digunakan untuk menguji pengaruh variabel bebas terhadap variabel bergantung secara parsial. Adapun pengambilan keputusan dalam uji t ini adalah sebagai berikut:

Jika nilai signifikansi lebih kecil daripada besarnya nilai tingkat signifikan (a) yaitu 0,05, maka $\mathrm{H}_{0}$ ditolak dan $\mathrm{H}_{1}$ diterima, dan sebaliknya.

\section{HASIL PENELITIAN DAN PEMBAHASAN}

Deskripsi karakteristik obyek penelitian, dalam penelitian ini akan menggambarkan karakteristik para reponden yaitu karyawan PT. Terafulk Megantara Design (TMD), yang berjumlah sekitar 50 responden. Karakteristik responden ini merupakan data pendukung dalam kuesioner yang meliputi jenis kelamin, usia, dan masa kerja.

Dalam penelitian ini responden diidentifikasikan berdasarkan berdasarkan jenis kelamin. Hasil identifikasi disajikan pada Tabel berikut : 
Tabel 4.1

Deskripsi Jenis Kelamin Responden

$\begin{array}{lll}\text { Jenis } & \text { Frekuensi } & \text { Presentase } \\ \text { Kelamin } & \text { Responden } & \\ \text { Laki- laki } & 44 & 88 \% \\ \text { Perempuan } & 6 & 12 \% \\ \text { Total } & \mathbf{5 0} & \mathbf{1 0 0 \%}\end{array}$

Sumber : Kuesioner diolah (Lampiran)

Berdasarkan usia. Hasil identifikasi disajikan pada Tabel berikut :

Tabel 4.2

Deskripsi Usia Responden

\begin{tabular}{|l|l|l|}
\hline Usia & $\begin{array}{l}\text { Frekuensi } \\
\text { Responden }\end{array}$ & Presentase \\
\hline $\begin{array}{l}< \\
\text { tahun }\end{array}$ & 17 & $34 \%$ \\
\hline $\begin{array}{l}25-35 \\
\text { tahun }\end{array}$ & 17 & $34 \%$ \\
\hline $\begin{array}{l}> \\
\text { tahun }\end{array}$ & 16 & $32 \%$ \\
\hline Total & $\mathbf{5 0}$ & $\mathbf{1 0 0 \%}$ \\
\hline
\end{tabular}

Sumber : Kuesioner diolah (Lampiran)

Dan berdasarkan masa kerjanya dalam perusahaan TMD. Hasil identifikasi disajikan pada Tabel berikut:

Tabel 4.3

Deskripsi Masa Kerja Responden

\begin{tabular}{|l|l|l|}
\hline $\begin{array}{l}\text { Masa } \\
\text { Kerja }\end{array}$ & $\begin{array}{l}\text { Frekuensi } \\
\text { Responden }\end{array}$ & Presentase \\
\hline$<1$ tahun & 11 & $22 \%$ \\
\hline $1-5$ tahun & 25 & $50 \%$ \\
\hline$>5$ tahun & 14 & $28 \%$ \\
\hline Total & $\mathbf{5 0}$ & $\mathbf{1 0 0 \%}$ \\
\hline
\end{tabular}

Sumber : Kuesioner diolah (Lampiran)

Dalam penulisan skripsi ini, hasil penelitian di lapangan akan ditabulasikan dan diajikan dalam bentuk deskripsi jawaban responden. Deskripsi menjelaskan hasil jawaban responden pada masing - masing indikator variabel penelitian berdasarkan frekuensi, rata rata setiap indikator variabel, dan kategori rata - rata. Untuk menentukan kategori nilai rata - rata, dapat diklasifikasikan berdasarkan interval kelas. Pada penelitian ini diketahui nilai tertinggi adalah empat sedangkan nilai terendah adalah satu, dan jumlah kelas atau kategori pada penelitian ini adalah empat. Dan hasilnya menunjukkan angka 0,75, yang merupakan jarak antar interval kelas pada masing - masing kelas. Sehingga ketentuan katerogi penilaian di peroleh sebagai berikut :

Tabel 4.4

Kategori Penilaian

\begin{tabular}{|l|l|}
\hline Interval Kelas & Kategori \\
\hline $1,00 \leq X \leq 1,75$ & Rendah \\
\hline $1,76 \leq X \leq 2,50$ & Sedang \\
\hline $2,51 \leq X \leq 3,25$ & Tinggi \\
\hline $3,26 \leq X \leq 4,00$ & $\begin{array}{l}\text { Sangat } \\
\text { Tinggi }\end{array}$ \\
\hline
\end{tabular}

Variabel komitmen organisasi dalam penelitian ini terdiri dari 6 indikator, berikut ini adalah Tabel hasil jawaban responden mengenai komitmen organisasi karyawan pada PT. Terafulk Megantara Design Surabaya dengan menggunakan metode pengambilan data melalui kuesioner, sebagai berikut :

\section{Tabel 4.5}


Deskripsi Variabel Komitmen

Organisasional $(X)$

\begin{tabular}{|c|c|c|c|c|c|c|c|c|}
\hline \multirow[t]{2}{*}{ No } & \multirow{2}{*}{$\begin{array}{r}\text { Pernya } \\
\text { taan }\end{array}$} & \multirow{2}{*}{$\mathrm{N}$} & \multicolumn{4}{|c|}{ Skor } & \multirow{2}{*}{ Mean } & \multirow{2}{*}{ Kategori } \\
\hline & & & 1 & 2 & 3 & 4 & & \\
\hline 1 & $X_{1.1}$ & 50 & 0 & 0 & 24 & 26 & 3,52 & $\begin{array}{c}\text { Sangat } \\
\text { Tinggi }\end{array}$ \\
\hline 2 & $X_{1.2}$ & 50 & 0 & 0 & 30 & 20 & 3,40 & $\begin{array}{c}\text { Sangat } \\
\text { Tinggi }\end{array}$ \\
\hline 3 & $X_{1.3}$ & 50 & 0 & 21 & 28 & 1 & 2,60 & Tinggi \\
\hline 4 & $X_{1.4}$ & 50 & 0 & 41 & 8 & 1 & 2,20 & Sedang \\
\hline 5 & $X_{1.5}$ & 50 & 0 & 0 & 23 & 27 & 3,54 & $\begin{array}{c}\text { Sangat } \\
\text { Tinggi }\end{array}$ \\
\hline 6 & $X_{1.6}$ & 50 & 0 & 0 & 24 & 26 & 3,52 & $\begin{array}{c}\text { Sangat } \\
\text { Tinggi }\end{array}$ \\
\hline
\end{tabular}

Sumber : Data diolah (Lampiran)

Dari Tabel 4.5 di atas, merupakan hasil deskripsi jawaban (tanggapan) responden dan dapat diinterprestasikan sebagai berikut :

Berdasarkan Tabel 4.5 dapat dilihat bahwa indikator $X_{1.3}$ dan $X_{1.4}$ memiliki nilai rata - rata paling rendah jika dibandingkan dengan indikator lainnya. Hasil ini menunjukkan bahwa sebagian karyawan merasa tidak setuju dengan kedua indikator tersebut. Sehingga dapat disimpulkan bahwa para karyawan memiliki alternatif kerja di tempat lain selain di perusahaan TMD, sehingga mereka tidak akan memiliki kesulitan dalam memenuhi kebutuhan hidupnya meskipun telah meninggalkan perusahaan.

Variabel kinerja Islami karyawan dalam penelitian ini terdiri dari 6 indikator. Berikut ini Tabel jawaban responden mengenai kinerja Islami karyawan pada PT. Terafulk Megantara Design Surabaya, berdasarkan kuesioner sebagai berikut :

Tabel 4.6

Deskripsi Variabel Kinerja Islami Karyawan $(Y)$

\begin{tabular}{|c|c|c|c|c|c|c|c|c|}
\hline \multirow[b]{2}{*}{ No } & \multirow{2}{*}{$\begin{array}{l}\text { Perny } \\
\text { ataa } \\
n\end{array}$} & \multirow[b]{2}{*}{$\mathrm{N}$} & \multicolumn{4}{|c|}{ Skor } & \multirow[b]{2}{*}{ Mean } & \multirow[b]{2}{*}{ Kategori } \\
\hline & & & 1 & 2 & 3 & 4 & & \\
\hline 1 & $Y_{1.1}$ & 50 & 0 & 2 & 35 & 13 & 3,22 & Tinggi \\
\hline 2 & $Y_{1.2}$ & 50 & 0 & 2 & 31 & 17 & 3,30 & $\begin{array}{c}\text { Sangat } \\
\text { Tinggi }\end{array}$ \\
\hline 3 & $Y_{1.3}$ & 50 & 0 & 1 & 32 & 17 & 3,32 & $\begin{array}{c}\text { Sangat } \\
\text { Tinggi }\end{array}$ \\
\hline 4 & $Y_{1.4}$ & 50 & 0 & 5 & 32 & 13 & 3,16 & Tinggi \\
\hline 5 & $Y_{1.5}$ & 50 & 0 & 1 & 33 & 16 & 3,30 & $\begin{array}{c}\text { Sangat } \\
\text { Tinggi }\end{array}$ \\
\hline 6 & $Y_{1.6}$ & 50 & 0 & 0 & 22 & 28 & 3,56 & $\begin{array}{c}\text { Sangat } \\
\text { Tinggi }\end{array}$ \\
\hline
\end{tabular}

Sumber : Data diolah (Lampiran)

Dari Tabel 4.6 di atas, merupakan hasil deskripsi jawaban (tanggapan) responden dan dapat diinterprestasikan sebagai berikut :

Berdasarkan Tabel 4.6, dapat dilihat bahwa semua indikator memiliki nilai rata - rata (mean) lebih dari 3,00 dan sebagian besar dikategorikan sangat tinggi. hal ini menunjukan bahwa para karyawan TMD selalu berusaha menyelesaikan pekerjaannya dengan ketentuan Islam yaitu dilaksanakan dengan itqon (tepat waktu, sesuai dengan tujuan, mencapai target yang diharapkan, dan dilakukan sebaik baiknya) serta sesuai dengan standar yang ditetapkan perusahan.

Untuk mengkorelasikan data uji validitas pada penelitian ini menggunakan rumus korelasi product moment dari pearson (Pearson productmoment correlation).

Tabel 4.7

Hasil Uji Validitas Variabel Komitmen Organisasional

\begin{tabular}{|l|l|l|l|l|}
\hline $\begin{array}{l}\text { Vari } \\
\text { abel }\end{array}$ & $\begin{array}{l}\text { Indik } \\
\text { ator }\end{array}$ & $\begin{array}{l}\text { Correlati } \\
\text { on } \\
\text { Pearson }\end{array}$ & $\begin{array}{l}\text { stand } \\
\text { ar }\end{array}$ & $\begin{array}{l}\text { Keteran } \\
\text { gan }\end{array}$ \\
\hline
\end{tabular}




\begin{tabular}{|l|l|l|l|l|}
\hline \multirow{2}{*}{$\begin{array}{l}\text { Komi } \\
\text { tme }\end{array}$} & $\mathrm{X}_{1.1}$ & 0,739 & 0,30 & Valid \\
\cline { 2 - 5 } & $\mathrm{X}_{1.2}$ & 0,828 & 0,30 & Valid \\
\cline { 2 - 5 } \multirow{2}{*}{$\begin{array}{l}\text { Org } \\
\text { anis } \\
\text { asi }\end{array}$} & $\mathrm{X}_{1.3}$ & 0,529 & 0,30 & Valid \\
\cline { 2 - 5 } & $\mathrm{X}_{1.4}$ & 0,508 & 0,30 & Valid \\
\cline { 2 - 5 } & $\mathrm{X}_{1.5}$ & 0,745 & 0,30 & Valid \\
\hline
\end{tabular}

Sumber : Data diolah (Lampiran)

Dari hasil uji validitas pada Tabel 4.7, menunjukkan nilai korelasi antara skor butir dengan skor total seluruh butir positif dan $r$ hitung $\geq 0,30$, maka dapat disimpulkan bahwa seluruh indikator mampu mengukur variabel komitmen organisasional sehingga dapat digunakan pada analisis selanjutnya.

Tabel 4.8

Hasil Uji Validitas Variabel Kinerja Islami Karyawan

\begin{tabular}{|c|c|c|c|c|}
\hline $\begin{array}{l}\text { Var } \\
\text { iab } \\
\text { el }\end{array}$ & $\begin{array}{l}\text { Indik } \\
\text { ator }\end{array}$ & $\begin{array}{l}\text { Correlatio } \\
\text { n Pearson }\end{array}$ & $\begin{array}{l}r \\
\text { stand } \\
\text { ar }\end{array}$ & $\begin{array}{l}\text { Keterang } \\
\text { an }\end{array}$ \\
\hline \multirow{6}{*}{$\begin{array}{l}\text { Kin } \\
\text { erja } \\
\text { Kar } \\
\text { ya } \\
\text { wa } \\
\text { n }\end{array}$} & $Y_{1.1}$ & 0,576 & 0,30 & Valid \\
\hline & $Y_{1.2}$ & 0,751 & 0,30 & Valid \\
\hline & $Y_{1.3}$ & 0,745 & 0,30 & Valid \\
\hline & $Y_{1.4}$ & 0,747 & 0,30 & Valid \\
\hline & $Y_{1.5}$ & 0,735 & 0,30 & Valid \\
\hline & $Y_{1.6}$ & 0,626 & 0,30 & Valid \\
\hline
\end{tabular}

Sumber : Data diolah (Lampiran)

Dari hasil uji validitas pada Tabel 4.8, menunjukkan nilai korelasi antara skor butir dengan skor total seluruh butir positif dan $r$ hitung $\geq 0,30$ maka dapat disimpulkan bahwa seluruh indikator dikatakan valid dan mampu mengukur variabel kinerja Islami karyawan sehingga dapat digunakan pada analisis selanjutnya.
Untuk mencari reliabilitas instrumen menggunakan alat ukur Alpha Cronbach (a) Apabila Alpha Cronbach (a) lebih besar 0,6 maka penelitian dikatakan reliabel dan cukup baik untuk digunakan sebagai input penelitian dalam proses pengumpulan data. Berikut ini adalah Tabel hasil uji reliabilitas untuk seluruh variabel :

Tabel 4.9

\section{Hasil Uji Reliabilitas pada Variabel}

Penelitian

\begin{tabular}{|c|c|c|c|c|}
\hline $\begin{array}{l}\text { Vari } \\
\text { abel }\end{array}$ & $\begin{array}{l}\text { Numb } \\
\text { er of } \\
\text { ltem }\end{array}$ & $\begin{array}{l}\text { Alpha } \\
\text { Cronba } \\
\text { nch }\end{array}$ & a standar & $\begin{array}{l}\text { Keteran } \\
\text { gan }\end{array}$ \\
\hline $\begin{array}{l}\text { Kom } \\
\text { itme } \\
n \\
\text { Org } \\
\text { anis } \\
\text { asio } \\
\text { nal } \\
(X)\end{array}$ & 6 & 0,778 & 0,6 & Reliabel \\
\hline $\begin{array}{l}\text { Kine } \\
\text { rja } \\
\text { Isla } \\
\text { mi } \\
\text { Kary } \\
\text { awa } \\
n(Y)\end{array}$ & 6 & 0,789 & 0,6 & Reliabel \\
\hline
\end{tabular}

Sumber : Data diolah (Lampiran)

Dari hasil uji reliabilitas pada Tabel 4.9, dapat disimpulkan bahwa instrumen pada penelitian ini dinyatakan memiliki reliabelitas yang baik untuk digunakan sebagai input penelitian dalam proses pengumpulan data. 
Uji statistik pada asumsi klasik yang akan digunakan untuk mengetahui adanya gejala penyimpangan yang diperlukan dalam penelitian ini, sebagai berikut :

\section{Uji Normalitas}

Normalitas residual dapat diketahui dengan cara melihat grafik P - P plot dan dengan menggunakan uji Kolmogorov Smirnov Test dimana asumsi normalitas terpenuhi jika menghasilkan P-Valve (Sign) > a sebesar 0,01,0,05. . Berikut ini adalah hasil gambar normalitas data:

\section{Regresi Linier Sederhana}

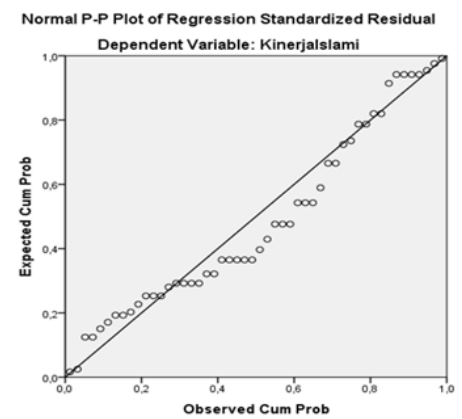

Sumber : Data diolah (Lampiran)

\section{Gambar 4.1}

\section{Grafik Normalitas P - P plot}

Dari gambar 4.1, menunjukkan model regresi diatas terdistribusi secara normal.

Tabel 4.10

Hasil Uji Kolmogorov Smirnov Test

\begin{tabular}{|l|l|l|}
\hline $\begin{array}{l}\text { Model } \\
\text { Regresi }\end{array}$ & Uji & $\begin{array}{l}\text { Unstandardize } \\
\text { d Residual }\end{array}$ \\
\hline Regresi & Kolmogoro & 0,963 \\
Linier & V-Smirnov Z & \\
\cline { 2 - 3 } $\begin{array}{l}\text { Sederhan } \\
\text { a }\end{array}$ & $\begin{array}{l}\text { Asymp. Sig. } \\
\text { (2-tailed) }\end{array}$ & 0,312 \\
\hline
\end{tabular}

Sumber : Data diolah (Lampiran)

Dari hasil uji Kolmogorov Smirnov Test pada Tabel 4.10, Nilai signifikan pada regresi di atas lebih besar dari nilai a, yaitu
0,05 . Hasil ini menunjukkan bahwa regresi linier sederhana dikatakan berdistribusi normal.

\section{Uji Heteroskedastisitas}

Uji heteroskedastisitas dapat dilakukan dengan metode grafik yaitu menggunakan metode scatter plot. Berikut ini adalah grafik hasil uji heteroskedastisitas:

\section{Regresi Linier Sederhana}

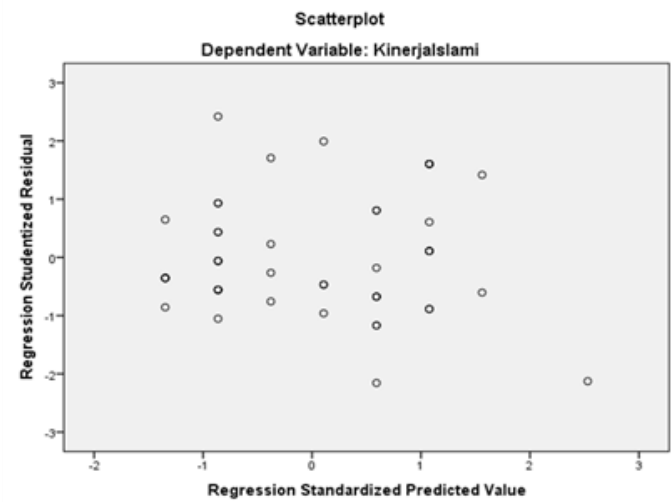

Sumber : Data diolah (Lampiran)

Gambar 4.2

\section{Grafik Uji Heteroskedastisitas}

Dari gambar 4.2, terlihat bahwa titik - titik pada grafik model regresi diatas menyebar dan tidak membentuk pola tertentu, dengan demikian terdapat kesamaan variansi dari residual satu pengamatan ke pengamatan yang lain tetap.

\section{Uji Regresi Linier Sederhana}

Berikut ini adalah hasil uji regresi linier sederhana yang bertujuan untuk menguji pengaruh variabel bebas yaitu Komitmen Organisasional $(X)$ terhadap Kinerja Islami Karyawan (Y), sebagai berikut :

Tabel 4.11

\section{Koefisien Regresi Linier Sederhana}

\begin{tabular}{|l|l|l|l|}
\hline \multirow{2}{*}{ Variabel } & \multicolumn{3}{|l|}{ Regresi Linier Sederhana } \\
\cline { 2 - 4 } & Koefisien & $\dagger$ & Sig. \\
\hline
\end{tabular}




\begin{tabular}{|c|c|c|c|}
\hline & Regresi & & \\
\hline Konstanta & 12,075 & $\begin{array}{l}4,49 \\
8\end{array}$ & $\begin{array}{l}0,00 \\
0\end{array}$ \\
\hline $\begin{array}{l}\text { Komitmen } \\
\text { Organisasio } \\
\text { nal }\end{array}$ & 0,415 & $\begin{array}{l}2,91 \\
7\end{array}$ & $\begin{array}{l}0,00 \\
5\end{array}$ \\
\hline$R$ & 0,388 & & \\
\hline $\mathrm{R}^{2}$ & 0,151 & & \\
\hline Uji F & 8,509 & & \\
\hline Signifikansi & 0,005 & & \\
\hline \multicolumn{4}{|c|}{ Sumber : Data diolah (Lampiran) } \\
\hline $\begin{array}{l}\text { Dari Tabel } 4 \\
\text { perhitungar } \\
\text { diatas, mak } \\
\text { persamaan } \\
\text { sebagai ber }\end{array}$ & $\begin{array}{l}\text { 1, berdo } \\
\text { egresi lir } \\
\text { dapat c } \\
\text { egresi lini } \\
\text { ut : }\end{array}$ & $\begin{array}{l}\text { hasil } \\
\text { lerhan } \\
\text { kan } \\
\text { arhano }\end{array}$ & \\
\hline
\end{tabular}

Kinerja Islami Karyawan $=12,075+0,415$ Komitmen Organisasional $+\mathrm{e}$

Koefisien regresi linier sederhana menunjukkan tanda positif, artinya adanya perubahan yang searah antar kedua variabel dimana Koefisien variabel komitmen organisasional sebesar 0,415, artinya apabila komitmen organisasional ditingkatkan satu persen maka kinerja islami karyawan akan mengalami peningkatan sebesar 0,415 dan sebaliknya apabila komitmen organisasional diturunkan satu persen maka kinerja islami karyawan akan menurun sebesar 0,415 . Nilai konstanta sebesar 12,075 yang berarti apabila tidak ada variabel lain maka nilai kinerja islami karyawan adalah 12,075.

\section{Koefisien Determinasi}

Hasil perhitungan statistik pada regresi linier sederhana diperoleh nilai $R^{2}$ atau koefisien determinasi sebesar 0,151.
Artinya kontribusi dari variabel komitmen organisasional terhadap kinerja islami karyawan adalah 15,1 \% sedangkan sisanya $84,9 \%$ dipengaruhi oleh variabel lain yang tidak masuk dalam model. Korelasi antara variabel $X$ dan $Y$ pada hasil regresi linier sederhana, diperoleh $R=$ 0,388 . Berdasarkan pedoman interprestasi koefisien korelasi menurut Sugiyono (2012), menunjukkan bahwa nilai korelasi regresi sederhana, variabel $X$ terhadap $Y$ dianggap memiliki tingkat hubungan yang rendah.

\section{Pembuktian Hipotesis}

Pembuktian hipotesis pada penelitian ini dilakukan dengan menggunakan uji $F$ dan uji t. Hipotesis : Komitmen organisasional berpengaruh signifikan terhadap kinerja islami karyawan pada PT. Terafulk Megantara Design Surabaya.

Pada hasil uji F diperoleh F statistik sebesar 8,059 dengan tingkat signifikan sebesar 0,005 . Hal ini menunjukkan nilai signifikan kurang dari 0,05 . Sedangkan pada hasil uji †, diperoleh $\dagger$ statistik sebesar 2,917 dengan tingkat signifikan sebesar 0,005. Dari hasil kedua uji ini membuktikan bahwa baik secara simultan maupun parsial komitmen organisasional berpengaruh secara signifikan terhadap kinerja islami karyawan pada PT. Terafulk Megantara Design, sehingga hipotesis penelitian ini diterima.

\section{Pembahasan}

Berdasarkan dari berbagai hasil uji yang telah dilakukan dapat dinyatakan bahwa penelitian ini sejalan dengan penelitian yang dilakukan oleh Negin Memari, Omid 
Mahdieh, Ahmad Barati Marnani (2013) yang berjudul " The impact of Organizational Commitment on Employees Job Performance."A study of Meli bank" dan penelitian Yetta Tri Nydia (2010) yang berjudul "Pengaruh Komitmen Organisasional terhadap Kinerja Karyawan Lapangan SPBU COCO Pertamina MT Haryono", dimana keduanya merupakan jurnal acuan pada penelitian ini. Ketiga penelitian ini sama - sama membuktikan bahwa secara simultan komitmen organisasional memiliki pengaruh positif dan signifikan terjadap kinerja karyawan. Namun pendekatan yang digunakan dalam penelitian ini adalah berbasis islami.

Selain itu, dari hasil penelitian ini dapat disimpulkan bahwa meskipun komitmen organisasional berpengaruh positif dan signifikan terhadap kinerja islami karyawan, namun faktanya korelasi hubungan antara komitmen organisasional para karyawan terhadap kinerja islami mereka di dalam perusahaan memiliki tingkat hubungan yang rendah. Oleh karena itu perlu adanya komitmen islam yang tertanam di dalam diri karyawan untuk lebih mewujudkan kinerja mereka secara islami di dalam perusahaan.

\section{Simpulan \& Saran}

Hasil regresi linier sederhana menunjukkan bahwa koefisien variabel komitmen organisasional bertanda positif dengan nilai sebesar 0,415 dan Berdasarkan hasil uji $F$ dan uji $t$, diperoleh $F$ statistik sebesar 8,059 dan $†$ statistik sebesar 2,917, dengan tingkat signifikan masing - masing sebesar 0,005. Hal ini menunjukkan bahwa keduanya memiliki nilai signifikan kurang dari 0,05 . Hal ini membuktikan bahwa baik secara simultan maupun parsial komitmen organisasional berpengaruh secara signifikan terhadap kinerja islami karyawan pada PT. Terafulk Megantara Design, sehingga hipotesis penelitian ini diterima.

\section{Saran}

Perlu adanya peningkatan terhadap suasana atau kondisi kerja yang dapat memenuhi harapan karyawan PT. TMD sehingga karyawan akan merasa senang dengan pekerjaan yang didapat serta fasilitas yang mendukung kegiatan kerja. Sehingga karyawan dapat bekerja dengan semangat, produktif, dan memberikan kinerja yang terbaik.

\section{Daftar Pustaka}

Al Qur'an dan Terjemahannya Juz 1 - 30, 2006. Edisi Terbaru. Departemen Agama Republik Indonesia. Jakarta : Pustaka Agung Harapan.

Al - Math, Faiz, Muhammad, DR. 2004. 1100 Hadits Terpilih (Sinar Ajaran Muhammad). Jakarta : Gema Insani Press.

Anshari, Endang Syaifudin. 2004. Wawasan Islam, Pokok - pokok Pikiran Tentang Paradigma dan Sistem Islam. Jakarta: Gema Insani Press.

Anshori, Muslich dan Sri Iswati. 2009. Buku Ajar Metodologi Penelitian Kuantitatif. Cetakan Pertama. Surabaya: Airlangga University Press.

Azizah. 2013. Pengaruh Motivasi Spiritual Islam Terhadap Kinerja Islam Karyawan BRISyariah KCl Surabaya Gubeng. Skripsi Tidak Diterbitkan. Surabaya. Fakultas Ekonomi Dan Bisnis Universitas Airlangga.

Irawan, S.Ag., M.Ag, Dr.Mul. 2014. Indikator Kinerja Islami dan Kinerja Konvensional Berdasarkan Teori dan Al Qur'an dan Hadist. Makalah Ekonomi Islam. Surabaya Fakultas Ekonomi Dan Bisnis Universitas Airlangga.

Jonathan, Suwarno. 2006. Metode Penelitian Kuantitatif dan Kualitatif. Yogyakarta : Graha IImu.

Liana, Lie. 2009. Penggunaan MRA dengan Spss untuk Menguji Pengaruh Variabel Moderating terhadap Hubungan antara Variabel Independen dan Variabel Dependen. Jurnal Teknologi Informasi DINAMIK. Volume XIV. No.2, 
Juli, (2009) : 90-97. Fakultas Ekonomi Universitas Stikubank Semarang

Madura, Jeff. 2007. Pengantar Bisnis. Edisi 4. Jilid 2. Terjemahan oleh Ali Akbar Yulianto dan Krista. Jakarta: Salemba Empat.

Manan, MA. 1995. Teori dan Praktik Ekonomi Islam.Yogyakarta : Dana Bhakti Wakaf.

Memari, Negin., Mahdieh, Omid dan Ahmad Barati Marnani. 2013. The impact of Organizational Commitment on Employees Job Performance. "A study of Meli bank". Interdiscipinary Journal of Contemporary Research in Business. Vol 5. No 5. September.

Nuriansyah, Fanda. 2013. Pengaruh Motivasi Kerja Terhadap Kinerja Karyawan PT. Terafulk Megantara Design Surabaya. Skripsi Tidak Diterbitkan. Malang. Fakultas Ekonomi Universitas Negeri Malang.
Nydia, Tri, Yetta. 2012. Pengaruh Komitmen Organisasional Terhadap Kinerja Karyawan Lapangan SPBU Coco Pertamina MT Haryono. Skripsi Tidak Diterbitkan. Jakarta. Universitas Indonesia.

Rasjid, Sulaiman. 1994. Figh Islam. Cetakan Ke Dua puluh tujuh. Bandung : Sinar Baru Algensido

Robbins, Stephen P and Timothy Judge. 2016. Perilaku Organsasi. Terjemahan oleh Ratna Saraswati dan Febriella Sirait . Jakarta : Salemba Empat.

Umam, Khaerul. 2012. Perilaku Organisasi. Cetakan Kedua. Bandung: Penerbit Pustaka Setia

Yudha, Prambara Elit. 2014. Pengaruh Motivasi Terhadap Komitmen Organisasional Pada Guru Madrasah Ibtidaiyah Islamiyah Kota Madiun. Skripsi Tidak Diterbitkan. Surabaya. Fakultas Ekonomi Dan Bisnis Universitas Airlanga 